DOI https://doi.org/10.30525/978-9934-26-117-6-34

\title{
РОЗВИТОК ІСЛАМСЬКОЇ КАЛІГРАФІЇ В СУДАНСЬКОМУ МИСТЕЦТВІ (КІН. ХХ СТ. - ПОЧ. ХХІ СТ.)
}

\author{
Карім Нажет \\ аспірантка кафедри теорії та історї мистецтва \\ Національна академія образотворчого мистецтва і архітектури \\ м. Київ, Україна
}

Використання традиційної ісламської каліграфії в рамках принципів сучасного мистецтва виразно простежується в мистецтві африканського модернізму, а саме у творчості представників «Хартумської школи» в Судані, відомої ще як рух Хуруфія. Розвиток модернізму в Судані відбувався у непростий історичний період (II пол. XX ст.). Модернізм в Судані мав свої особливості, спричинені колоніальними та постколоніальними процесами, художники звертались до традиційного мистецтва, поєднували африканські мотиви 3 класичною арабською каліграфією.

У дослідженнях зарубіжних науковців таких як Салах М. Хассан [1, 2], Самір Амір [3], Джефф Дональдсон [4], Діпеш Чакрабарті [5], Стюарт Холл [6] та інших, висвітлено загальні питання історії та розвитку мистецтва модернізму II пол. XX ст. в Судані. Маловивченою досі лишається мистецька діяльність окремих художників II пол. XX ст. та митців які досі у своїй творчості використовують арабську каліграфію як графічну форму, нерелігійного характеру. Треба зазначити, що до середини XX ст. арабська каліграфія в Судані використовувалась винятково у релігійних цілях.

У 40 х. pр. молоді митці отримували художню освіту в Судані, багато з них продовжував навчання у Великобританії, в результаті чого, вплив західної академічної школи був неминучий, африканська традиція почала поступово занепадати. Унікальним винятком був Осман Вакіалла, він вважається новатором у мистецтві ісламської каліграфії на території Судану. Оволодівши мистецтвом красивого почерку, ретельно дослідивши композицію, збалансованість маси світлого і темного в каліграфії, Осман почав експериментувати з формами літер у своїх композиціях [7]. В той період часу революційна ідея стосовно традиційної каліграфії є незаперечною, це чітко простежується в роботі «Surat Al Baqara», створеної у 1970 році, сміливі каліграфічні написи виконані чорнилами на папері ручної роботи [8]. 
Осман Вакіалла (1925-2007), Ахмад Мохаммед Шибрайн (1931-2017), Тег ель-Сер Ахмед (нар. у 1933) та Ібрагім Ель-Салахі (нар. у 1930) були засновниками «Хартумської школи». Концепція їх творчості полягала у звільненні арабської каліграфії від іiї традиційної асоціації з Кораном, через сміливі деформації та руйнування класичних форм арабських літер. Слова та літери які застосовувались у творах, за формою були близькі до абстракції. Мотиви та образи суданські митці черпали 3 чисельних африканських, ісламських та європейських візуальних джерел. Новаторській підхід до арабської каліграфії, виявився надзвичайно впливовим серед тогочасних художників, що спричинило виникнення «Хартумської школи» [9]. До складу «Хартумської школи» входили студенти коледжу в якому викладав Осман Вакіалла, вони мали спільну мету: створення нового мистецького руху в Судані.

У листопаді 2016 року мистецький фонд Шарджа, який знаходится в Об'єднаних Арабських Еміратах, організував історичний огляд модерністського мистецького руху в Судані від середини XX століття до наших днів [10]. На виставці були продемонстровані каліграфічні роботи виконані в різних техніках і матеріалах: олівцем, маслом, аквареллю й інш.

Ці художники мали неабиякий вплив на подальше покоління митців, таких як Хасан Муса, він використовує каліграфію для передачі повідомлень, які не завзжди зрозумілі для публіки, залишаючи розум глядача відкритим для роздумів того, що перед ним. Хуссейн Хальфаві поєднує африканські мотиви з ісламською каліграфією, на тему згадок про сільське життя в долині Нілу, також представниками сучасного мистецтва є: Абушарія Ахмед, Махджуб Хасан Аль Авад та інші. Об'єднує майже всіх митців критичний погляд на західне мистецтво, спричинений колоніальними та постколоніальними процесами.

Використання каліграфії має безмежні можливості у творчих задумах сучасних митців. Це мистецтво не втрачає своєї актуальності у наші часи, а навпаки, зберігається і розвивається. Колекціонуються твори Музеєм сучасного мистецтва (МоМА), Музеєм сучасного мистецтва в Нью-Йорку, Музеєм африканського мистецтва у Вашингтоні, Арабським музеєм сучасного мистецтва в Досі, Катар і тд.

У цьому зв'язку акцентується потреба грунтовного розгляду мистецького доробку окремих суданських митців кінця XX - початку XXI ст. таких як: Осман Вакіалла, Ахмад Мохаммед Шибрайн, Ібрагім Ель-Салахі, Хасан Муса, Хуссейн Хальфаві, Абушарія Ахмед, Махджуб Хасан Аль Авад та інших. Для більшого розуміння як 
новаторський підхід до арабської каліграфії з середини XX століття продовжую розвиватись у наш час.

Унікальний внесок суданських митців та їх роль у формуванні сучасного мистецтва арабської каліграфії $є$ неоціненним та потребує подальшого дослідження. Діяльність Османа Вакіалла, Ахмада Мохаммеда Шибрайна, Тега ель-Сера Ахмеда та Ібрагіма Ель-Салахі $\epsilon$ яскравою сторінкою культурного і педагогічного життя Судану кінця $\mathrm{XX}$ ст. Рух Хуруфія є для суданський митців інструментом, який дав змогу здійснити національну модернізацію, відродження національної ідентичності яка була репресована в колоніальні часи. Усвідомлення важливості власної культурної спадщини, переосмислення пройденого та пошуки нових експериментів у мистецтві.

\section{Лiтература:}

1. Salah H. The Modernist Experiencein African Art: Visual Expression of the Self and Cross-Cultural Aesthetics, in: Olu Oguibe and Okwui Enwezor, ed. Reading the Contemporary: African Art from Theory to the Marketplace. London, 1999. Pp. 214-235.

2. Salah H. African Modernism: Beyond Alternative Modernities Discourse. South Atlantic Quarterly 109, no. 3. 2010. Pp. 451-473.

3. Samir A. Eurocentrism. New York. 1989.

4. Donaldson J. AfriCobra and TransAtlantic Connections, in: Clementine Deliss, ed., Seven Stories about Modern Art in Africa. Paris, 1995. Pp. 249-251.

5. Chakrabarty D. Provincializing Europe: Postcolonial Thought and Historical Difference. N.J., 2000.

6. Hall S., Maharaj S. Museums of Modern Art and the End of History, in: Modernity and Difference. London, 2001. pp. 21-22.

7. Hopkins, P. Osman Waquialla in Kenana Handbook Of Sudan, P. 462.

8. Rose Issa Projects URL: http://www.roseissa.com/past\%20exhib/ Signs-Traces-Calligraphy/past-exh33-5.html (дата звернення: 13.07.2021).

9. Salah H. Ibrahim El-Salahi and the Making of African and Transnational Modernism. URL: https:/universes.art/fileadmin/media/ images/nafas/2013/ibrahim_el_salahi/Ibrahim_El-SalahiEssay_Salah_Hassan-eng.pdf (дата звернення: 13.07.2021).

10. The Khartoum School: The Making of the Modern Art Movement in Sudan (1945 - present) URL: http://sharjahart.org/sharjah-art-foundation/exhibitions/the-khartoum-school-the-making-of-the-modern-artmovement-in-sudan-1945-pre (дата звернення: 13.07.2021). 